\title{
Cardamonin Inhibits the Expression of Inducible Nitric Oxide Synthase Induced by TLR2, 4, and 6 Agonists
}

\author{
Ah-Yeon Kim ${ }^{1,}$, Hyun-Jin Shim ${ }^{1,}$, Su-Yeon Kim ${ }^{1}$, Sung-Hye Heo ${ }^{1}$ and Hyung-Sun Youn ${ }^{1, \dagger}$ \\ ${ }^{1}$ Department of Biomedical Laboratory Science, College of Medical Sciences, \\ SoonChunHyang University, Chungnam, Asan 31538, Korea
}

Toll-like receptors (TLRs) play an important role for host defense against invading pathogens. The activation of TLRs signaling leads to the activation of NF- $\mathrm{KB}$ and the expression of pro-inflammatory gene products such as cytokines and inducible nitric oxide synthase (iNOS). To evaluate the therapeutic potential of cardamonin, which is a naturally occurring chalcone from Alpinia species (zingiberaceous plant species), NF- $\mathrm{BB}$ activation and iNOS expression induced by MALP-2 (TLR2 and TLR6 agonist) or LPS (TLR4 agonist) were examined. Cardamonin inhibited the activation of NF- $\kappa \mathrm{B}$ induced by MALP-2 or LPS. Cardamonin also suppressed the iNOS expression induced by MALP-2 or LPS. These results suggest that cardamonin has the specific mechanism for anti-inflammatory responses by regulating of TLRs signaling pathway.

Key Words: Cardamonin, Inducible nitric oxide synthase, TLR, Inflammation, LPS

\section{서 론}

염증은 미생물 감염 또는 조직 손상 후 발생하는 복잡 한 일련의 반응으로, 주로 발적, 부기, 발열 및 장기 통증 을 유발하지만, 외부의 계속된 자극에 반응하여 생성되는 만성 염증은 오히려 여러 질병을 유도하는 것으로 알려 져 있다(Ferrero-Miliani et al., 2007). 염증은 여러 질병과 관 련이 있는 병태생리학(pathophysiology)적인 현상으로, inducible nitric oxide synthase (iNOS)와 cyclooxygenase-2 (COX2) 효소가 염증 유발에 중요한 기능을 하는 것으로 알려 져 있다(Murakami and Ohigashi, 2007). iNOS는 nitric oxide (NO)를 생성하고, COX-2는 prostaglandins (PGs)을 생성한 다(Moncada, 1999; Turini and DuBois, 2002). 특히 iNOS의 free radical인 NO가 세포 독성 효과로 유발되는 염증과 관 련된 질병을 유도하는 것으로 알려져 있다(Vallance, 2003).
Toll-like receptors (TLR)는 비특이적 또는 타고난 면역 방어, 특히 세균, 바이러스, 진균 및 기생충을 포함한 병원 균 침입에 따른 염증 반응에 중요한 역할을 하는 병원체 인식 수용체로 알려져 있다(Kawai and Akira, 2010). 현재 포유류 세포에서 적어도 13 개의 TLRs가 발견되었으며, 박 테리아, 바이러스 등을 포함한 다양한 병원체 관련 분자 패턴들을(PAMPs) 인식한다(Kawai and Akira, 2010; Youn, 2012). TLR1 / 2 / 4 / 5 / 6 수용체는 세포 표면에 존재하여 미생물 분자 패턴들을(PAMPs) 인식하며, TLR3 / 7 / 9 수용 체는 엔도좀(enodosome)에 존재하여 미생물 핵산들을 인 식한다(Kawai and Akira, 2010). TLRs은 선천성 면역과 후천 성 면역 사이의 중요한 연결 고리이다. 그러므로 TLRs 신 호전달 시스템 조절 기전 규명은 여러 질병들을 예방하기 위하여 중요한 역할을 하게 될 것이다.

알피니아 식물(Alpinia, zingiberaceous plant species) 추출물 중의 하나인 cardamonin (2',4'-dihydroxy-6'-methoxychalcone)

\footnotetext{
* Received: April 16, 2018 / Revised: June 11, 2018 / Accepted: June 15, 2018

${ }^{\S}$ Both authors contributed equally to this work.

${ }^{\dagger}$ Corresponding author: Hyung-Sun Youn. Department of Biomedical Laboratory Science, College of Medical Sciences, SoonChunHyang University, Chungnam, Asan 31538, Korea.

Tel: +82-41-530-3086, Fax: +82-41-530-3085, e-mail: hyoun@sch.ac.kr

(C) The Korean Society for Biomedical Laboratory Sciences. All rights reserved.

(c) This is an Open Access article distributed under the terms of the Creative Commons Attribution Non-Commercial License (http://creativecommons.org/licenses/by-nc/3.0/) which permits unrestricted non-commercial use, distribution, and reproduction in any medium, provided the original work is properly cited.
} 


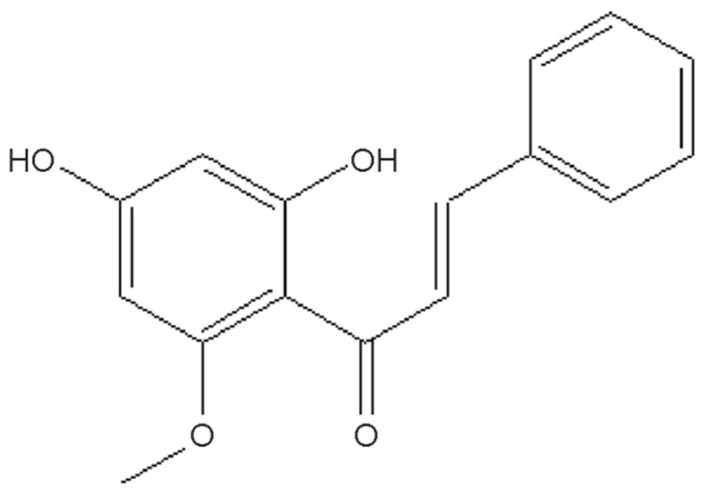

Fig. 1. The structure of cardamonin.

(Fig. 1)은 항염증 효능을 가지고 있는 chalcone 구조를 가 지고 있는 천연물질이다(Goncalves et al., 2014). Cardamonin 은 항염증(anti-inflammatory) (Chow et al., 2012), 항종양(antitumor) (Park et al., 2013), 항결핵(antituberculosis) (Lin et al., 2002), 혈소판 응고 억제를(platelet aggregation inhibitory) (Jantan et al., 2008) 포함한 여러 약리학적인 효능을 가지고 있는 것으로 알려져 있다. 하지만 이러한 cardamonin의 약 리학적인 작용 기전은 완전히 밝혀져 있지 않다. 또한 TLRs의 비정상적인 작동은 많은 만성염증 질환과 관련이 있는 것으로 알려져 있다. 그러므로 이번 연구에서는 cardamonin이 TLRs 신호전달 시스템을 조절하여, iNOS를 포 함한 염증 반응에 어떠한 영향을 미치는지를 알아보고자 한다.

\section{재료 및 방법}

재료

실험에 사용한 MALP-2 (macrophage-activating lipopeptide of $2 \mathrm{kDa}$ )와 LPS (lipopolysaccharide)는 Alexis Biochemical (San Diego, CA, USA)과 List Biological Lab (San Jose, CA, $\mathrm{USA}$ )로부터 각각 구입하였으며, $\mathrm{iNOS}$ 와 $\beta$-actin 항체는 BD Biosciences (San Jose, CA, USA)와 Santa Cruz Biotechnology (Santa Cruz, CA, USA) 회사로부터 각각 구입하였다. 그 밖의 다른 시약들은 Sigma-Aldrich 회사로부터 구입하 였다.

\section{세포 배양}

RAW264.7 세포들은(a murine monocytic cell line, ATCC TIB-71) 10\% (v/v) FBS, 100 units/mL Penicillin, $100 \mu \mathrm{g} / \mathrm{mL}$ streptomycin이 포함된 Dulbecco's modified Eagle's medium $(\mathrm{DMEM})$ 을 사용하여, $5 \% \mathrm{CO}_{2} / \mathrm{air}, 37^{\circ} \mathrm{C}$ 에서 배양하였다.

\section{Plasmid}

NF- $\kappa B$ 와 iNOS 발광 plasmid는 F. Mercurio (Signal Pharmaceuticals, San Diego, CA, USA)와 Daniel Hwang (University of California, Davis, CA, USA)으로부터 각각 제공받았으 며, Heat shock protein (HSP) 70- $\beta$-galactosidase plasmid는 R. Modlin (University of California, Los Angeles, CA, USA)으로부 터 제공받았다. 위의 모든 DNA는 EndoFree Plasmid Maxi kit (Qiagen, Valencia, CA, USA)을 사용하여 준비되었다.

\section{Transfection과 발광효소 유전자 분석(luciferase re- porter gene assay)}

NF- $\kappa B$ 와 iNOS 발광효소 유전자 분석은 transfection 방 법을 사용하여 분석하였다(Youn et al., 2005; Youn et al., 2006c). RAW264.7 세포를 well plates에 균등 분주하였고, overnight 후 50 60\% 정도의 증식을 보일 때, 발광효소 plasmid와 HSP70- $\beta$-galactosidase plasmid는 Superfect transfection 시약(Qiagen, Valencia, CA, USA)을 사용하여 세포 안으로 transfection 시켰다. Luciferase assay system (Promega, Madison, WI, USA)을 사용하여 발광효소의 활성화를 측정 하였으며, $\beta$-galactosidase의 활성화를 측정하여 표준화시 켰다.

\section{Immunoblotting}

세포로부터 추출된 단백질들은 SDS-PAGE (sodium dodecyl sulfate-polyacrylamide gel electrophoresis)에서 크기에 따라 분리되었으며, 전기영동에 의해서 polyvinylidene difluoride membrane으로 이동되었다(Youn et al., 2006a; Youn et al., 2006b). Membrane은 0.1\% Tween 20와 5\% 탈지 건조된 우유를 포함하고 있는 phosphate-buffered saline에서 하루 동안 blocking을 하였으며, 측정하고자 하는 단백질의 1차 항체를 붙이고, horseradish peroxidase가 결합된 2차 항체를 붙인 다음에, iNtRON western blot detection system (Seongnam, Gyeonggi-do, Korea)을 사용하여 원하는 단백질을 측정하 였다.

\section{Nitrite assay}

RAW264.7 세포로부터 nitrite 추출물을 선행연구 방법에 따라서 준비하였다(Lim et al., 2008). 세포 배양 플레이트의 상층액에 분주기를 사용하여 Griess reagent를 첨가하였으 
A

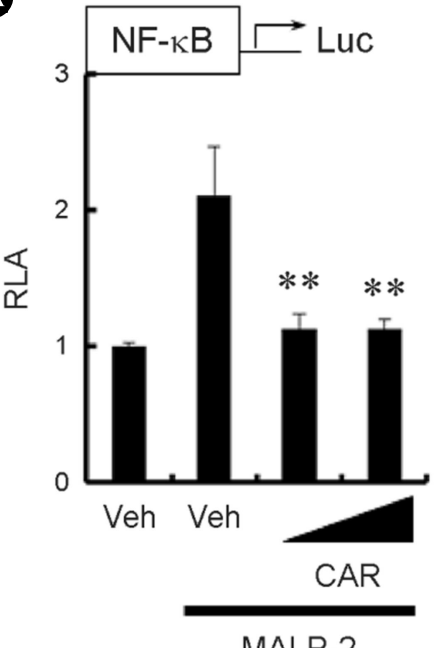

B

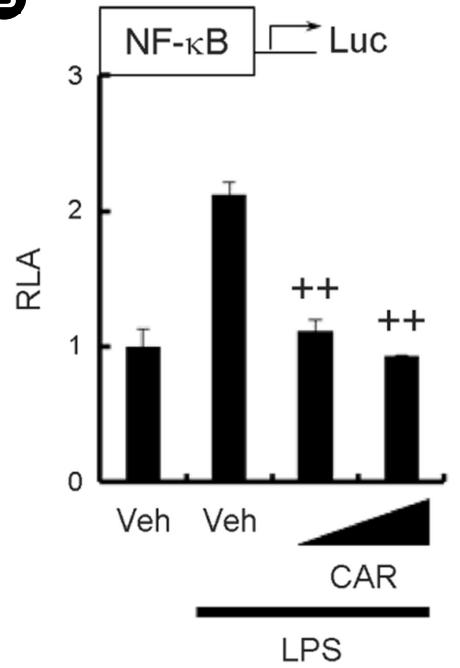

Fig. 2. Cardamonin inhibits NF- $\kappa \mathrm{B}$ activation induced by MALP-2 or LPS. (A) RAW 264.7 cells were transfected with NF-kB-luciferase reporter plasmid and pre-treated with cardamonin $(30,50 \mu \mathrm{M})$ for $1 \mathrm{~h}$ and then treated with MALP-2 $(10 \mathrm{ng} / \mathrm{mL})(\mathrm{A})$ or LPS $(10 \mathrm{ng} / \mathrm{mL})(B)$ for an additional $8 \mathrm{~h}$. Cell lysates were prepared and luciferase and $\beta$-galactosidase enzyme activities were measured as described in Materials and Methods. Relative luciferase activity (RLA) was normalized with $\beta$-galactosidase activity. Values are mean \pm SEM $(n=3)$. *, Significantly different from MALP-2 alone, $P<0.01(* *)(\mathrm{A}) .+$, Significantly different from LPS alone, $P<0.01(++)(\mathrm{B})$. Veh, vehicle; CAR, cardamonin.
며, plate reader를 사용하여 $570 \mathrm{~nm}$ 에서 흡광도를 측정하였 다. 표준용액으로 sodium nitrite를 사용하였다.

\section{데이타 분석}

각각의 데이타 값은 세 개가 한 벌의 실험으로 얻어졌 으며, mean \pm standard error mean (SEM)으로 표현되었다.

\section{결과 및 고찰}

Cardamonin은 TLR2와 TLR6 또는 TLR4 agonists에 의해 서 유도된 NF- $\mathrm{kB}$ 활성화를 억제하였다.

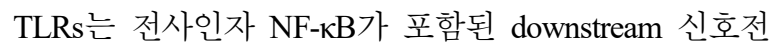
달체계를 활성화시킨다(Akira and Takeda, 2004). 여러 병원 체들에 의해 활성화된 신호들은 NF- $\kappa \mathrm{B}$ 억제제 $\mathrm{I} \kappa \mathrm{B} \alpha$ 를 인 산화(phosphorylation) 시키며, 인산화된 $\mathrm{I} \kappa \mathrm{B} \alpha$ 는 $26 \mathrm{~S}$ proteasome에 의해서 분해되어 NF- $\mathrm{KB}$ 를 활성화시킨다. 활성화 된 NF-kB는 핵(nucleus) 안으로 전좌(translocation)되어 타 깃 유전자의 DNA에 결합하여 전사(transcription)를 유도해 여러 단백질을 만들게 된다(Pahl, 1999: Ghosh and Karin, 2002). 우리는 NF-kB 발광효소 유전자 분석실험을 통해 $\mathrm{NF}-\kappa \mathrm{B}$ 활성에 대한 Cardamonin의 효능을 측정하였다. Cardamonin은 MALP-2 (TLR2와 TLR6 agonist) 또는 LPS (TLR4 agonist)에 의해 유도된 NF-kB 활성을 억제하였다 (Figs. 2A, 2B).

Cardamonin은 TLR2와 TLR6 또는 TLR4 agonists에 의해 서 유도된 iNOS의 발현을 억제하였다.

다음 실험으로 cardamonin이 NF-kB 활성화에 의해서 유
도되는 유전자인 $\mathrm{iNOS}$ 의 생성에 어떠한 영향을 미치는지 알아보았다. 먼저 $\mathrm{iNOS}$ 발광효소 유전자 분석법에 의하면 cardamonin은 MALP-2 또는 LPS에 의해 유도된 iNOS의 과발현을 억제시켰다(Figs. 3A, 3B). Cardamonin은 MALP-2 또는 LPS에 의해 유도된 iNOS 단백질 과발현을 억제시키 는 것을 Western blotting 방법을 통하여 확인하였다(Figs. 3C, 3D). 또한 Cardamonin은 MALP-2 또는 LPS에 의해서 유도된 iNOS의 생성물인 nitrite의 생성을 억제시켰다(Figs. 4A, 4B). 이러한 결과들은 cardamonin이 TLR agonists에 의 해서 유도된 $\mathrm{iNOS}$ 를 조절할 수 있다는 것을 보여주는 결 과라 할 수 있겠다.

공기중의 가장 풍부한 질소와 산소 두 기체의 $1: 1$ 조합 물인 $\mathrm{NO}$ 는 1987 년까지 전기화학반응의 부산물로 여겨져 왔다(Hanafy et al., 2001). 하지만 지금 $\mathrm{NO}$ 는 동물 세포에 서 L-arginine 아미노산으로부터 만들어지고, 이 $\mathrm{NO}$ 는 세 포에서 다른 세포 사이의 신호전달을 위해 사용하는 것으 로 알려져 있다(Hanafy et al., 2001). NO는 endothelial NOS (eNOS), neuronal NOS (nNOS)와 inducible NOS (iNOS)인 3 개의 NOSs에 의해서 만들어진다(Vallance, 2003). eNOS와 $\mathrm{nNOS}$ 는 일정하게 발현되어 있는 효소인데 반해서, $\mathrm{iNOS}$ 는 감염이나 염증성 인자(proinflammatory stimuli)에 의해 서 유도되는 효소이다(Vallance, 2003). 특히 NOS isoforms 중에서, $\mathrm{iNOS}$ 의 과발현이 동물의 병태생리학과 가장 관계 가 있는 것으로 알려져 있다(Green et al., 1990). 일반적으 로 대식 세포에서 iNOS는 발현되지 않지만, LPS를 포함 한 다양한 염증 자극제에 의해서 $\mathrm{iNOS}$ 유전자가 활성화 되어, iNOS 단백질이 만들어진다(Palmer et al., 1993). iNOS 
A

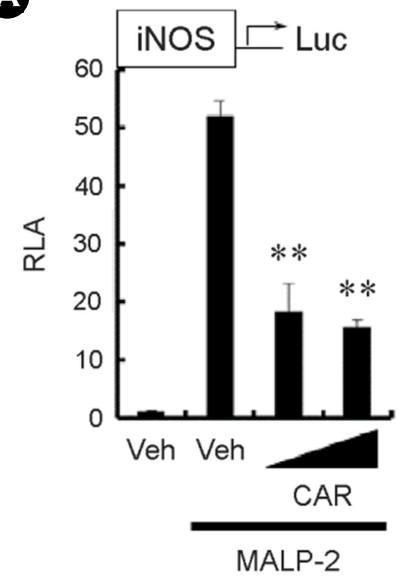

C

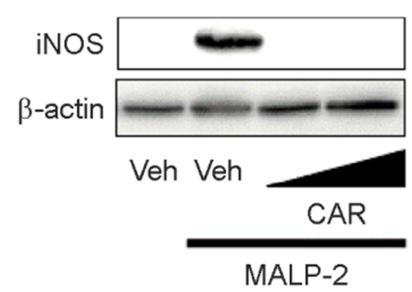

A

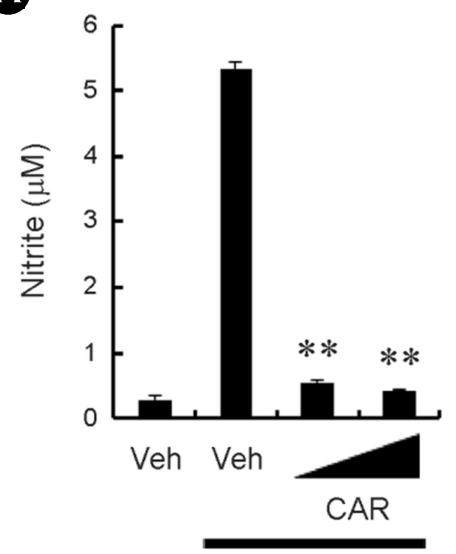

MALP-2
B

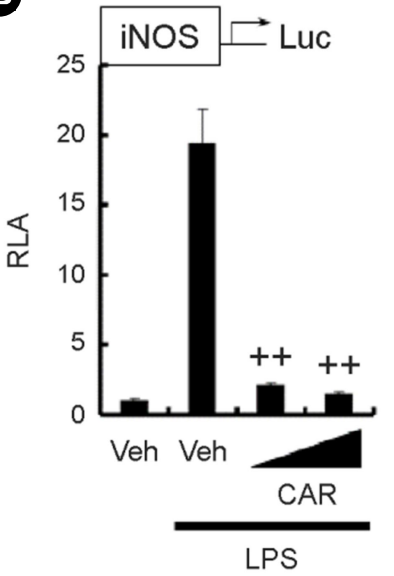

D

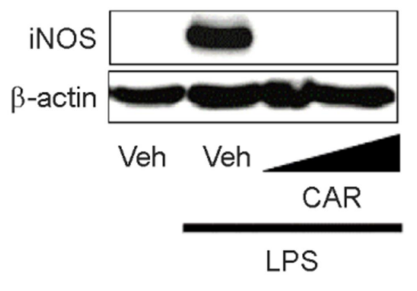

B

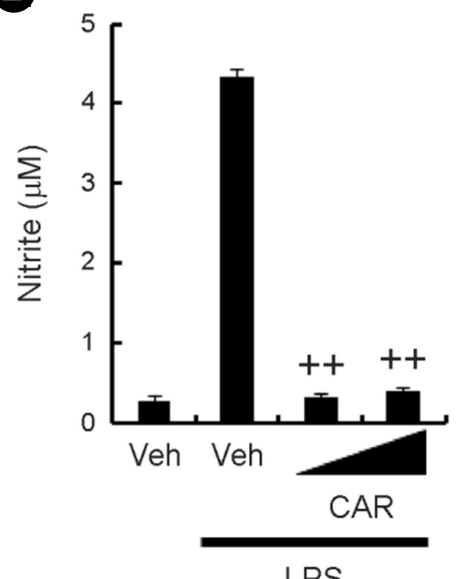

Fig. 3. Cardamonin inhibits iNOS expression induced by MALP-2 or LPS. (A, B) RAW 264.7 cells were transfected with iNOS luciferase reporter plasmid and pretreated with 30 or $50 \mu \mathrm{M}$ cardamonin for $1 \mathrm{~h}$ and then treated with MALP-2 $(10 \mathrm{ng} / \mathrm{mL})$ (A) or LPS $(10 \mathrm{ng} / \mathrm{mL})$ (B) for an additional $8 \mathrm{~h}$. Cell lysates were prepared and luciferase enzyme activities were determined. Values represent the mean \pm SEM $(\mathrm{n}=3) . *$, Significantly different from MALP-2 alone, $P<0.01(* *)$ (A). +, Significantly different from LPS alone, $P<0.01(++)$ (B). (C, D) RAW 264.7 cells were pretreated with 30 or $50 \mu \mathrm{M}$ cardamonin for $1 \mathrm{~h}$ and then further stimulated with MALP-2 $(10 \mathrm{ng} / \mathrm{mL})$ (C) or LPS $(10 \mathrm{ng} / \mathrm{mL})$ (D) for $8 \mathrm{~h}$. Cell lysates were analyzed for iNOS and $\beta$-actin protein by immunoblots. Veh, vehicle; CAR, cardamonin.

Fig. 4. Cardamonin inhibits nitrite production induced by MALP-2 or LPS. (A, B) RAW 264.7 cells were pretreated with 30 or $50 \mu \mathrm{M}$ cardamonin for $1 \mathrm{~h}$ and then treated with MALP-2 $(10 \mathrm{ng} / \mathrm{mL})$ (A) or LPS $(10 \mathrm{ng} / \mathrm{mL})$ (B) for an additional $20 \mathrm{~h}$. The amounts of nitrite in supernatant were measured using Griess reagent. Values represent the mean $\pm \operatorname{SEM}(\mathrm{n}=3)$. *, Significantly different from MALP-2 alone, $P<0.01$ (A). +, Significantly different from LPS alone, $P<0.01(+)$ (B). Veh, vehicle; CAR, cardamonin.

에 의해서 생성되는 부산물인 $\mathrm{NO}$ 는 peroxynitrite를 형성 하기 위하여 $\mathrm{O}_{2}$ 와 결합했을 때, 여러 효소와 신호전달체 계에 영향을 미치는 것으로 알려져 있다(Vallance, 2003).

TLRs는 각각 서로 다른 자극제를 인식하여 신호전달 시스템을 유도하는 것으로 알려져 있다(Kawai and Akira, 2010). TLRs가 자극제를 인식하면 최초 반응으로 TLRs 가 동종이합체를 형성한다. TLRs의 동종이합체 형성은 어
댑터 분자(adaptor molecule)인 myeloid differential factor 88 (MyD88) 또는 TIR domain-containing adaptor inducing interferon- $\beta$ (TRIF)를 유도하며, 결국 전사요소 NF- $\mathrm{KB}$ 나 interferon regulatory factor 3 (IRF3)의 활성화를 유도한다 (Kawai and Akira, 2010). 전사요소의 활성화는 결국 cytokine, iNOS와 같은 inflammatory gene products를 유도하여 여러 질병을 유도하게 된다(Akira and Takeda, 2004). 그러 
므로 TLRs의 신호전달 시스템을 조절할 수 있다면 여러 병원균들로부터 유도되는 염증 반응이나 만성적인 질병들 을 막거나 치유할 수 있게 되는 것이다.

우리는 이번 연구에서 cardamonin이 TLRs 자극제인 MALP-2와 LPS에 의해서 유도된 전사 요소 NF- $\mathrm{kB}$ 활성 화 및 그것에 의해서 유도되는 $\mathrm{NOS}$ 단백질 발현에 어떤 영향을 미치는지 알아보았다. Cardamonin은 MALP-2와 LPS에 의해서 유도된 NF- $\mathrm{KB}$ 활성화와 $\mathrm{iNOS}$ 의 과발현을 억제시켰다. 이러한 결과는 cardamonin이 TLRs 신호전달 시스템을 조절하여 염증 반응과 같은 만성적인 질병들을 치유할 수 있다는 것을 보여주는 중요한 결과라 할 수 있 겠다. 이러한 연구는 앞으로 염증 작용 기전 규명 및 항염 증제 개발에 중요한 역할을 할 것으로 기대한다.

\section{ACKNOWLEDGEMENTS}

본 연구는 순천향대학교 학술연구비의 일부 지원과 2017년도 한국연구재단의 지원을 받아 수행된 기초연구 사업(2017R1D1A1B03031534)의 지원을 받아 수행된 연구 결과물로 그 지원에 감사 드립니다.

\section{CONFLICT OF INTEREST}

The authors have no conflicts of interest to disclose.

\section{REFERENCES}

Akira S, Takeda K. Toll-like receptor signalling. Nat Rev Immunol. 2004. 4: 499-511.

Chow YL, Lee KH, Vidyadaran S, Lajis NH, Akhtar MN, Israf DA, Syahida A. (Cardamonin from Alpinia rafflesiana inhibits inflammatory responses in IFN-gamma/LPS-stimulated BV2 microglia via NF-kappaB signalling pathway. Int Immunopharmacol. 2012. 12: 657-665.

Ferrero-Miliani L, Nielsen OH, Andersen PS, Girardin SE. Chronic inflammation: importance of NOD2 and NALP3 in interleukin1beta generation. Clin Exp Immunol. 2007. 147: 227-235.

Ghosh S, Karin M. Missing pieces in the NF-kappaB puzzle. Cell. 2002. 109 Suppl: S81-96.

Goncalves LM, Valente IM, Rodrigues JA. An overview on cardamonin. J Med Food. 2014. 17: 633-640.

Green SJ, Meltzer MS, Hibbs JB Jr, Nacy CA. Activated macrophages destroy intracellular Leishmania major amastigotes by an L-arginine-dependent killing mechanism. J Immunol. 1990. 144: 278-283.
Hanafy KA, Krumenacker JS, Murad F. NO, nitrotyrosine, and cyclic GMP in signal transduction. Med Sci Monit. 2001. 7: 801-819.

Jantan I, Raweh SM, Sirat HM, Jamil S, Mohd Yasin YH, Jalil J, Jamal JA. Inhibitory effect of compounds from Zingiberaceae species on human platelet aggregation. Phytomedicine. 2008 15: 306-309.

Kawai T, Akira $\mathrm{S}$. The role of pattern-recognition receptors in innate immunity: update on Toll-like receptors. Nat Immunol. 2010. 11: 373-384.

Lim HJ, Lee HS, Ryu JH. Suppression of inducible nitric oxide synthase and cyclooxygenase- 2 expression by tussilagone from Farfarae flos in BV-2 microglial cells. Arch Pharm Res. 2008. 31: 645-652.

Lin YM, Zhou Y, Flavin MT, Zhou LM, Nie W, Chen FC. Chalcones and flavonoids as anti-tuberculosis agents. Bioorg Med Chem. 2002. 10: 2795-2802.

Moncada S. Nitric oxide: discovery and impact on clinical medicine. J R Soc Med. 1999. 92: 164-169.

Murakami A, Ohigashi H. Targeting NOX, INOS and COX-2 in inflammatory cells: chemoprevention using food phytochemicals. Int J Cancer. 2007. 121: 2357-2363.

Pahl HL. Activators and target genes of Rel/NF-kappaB transcription factors. Oncogene. 1999. 18: 6853-6866.

Palmer RM, Hickery MS, Charles IG, Moncada S, Bayliss MT. Induction of nitric oxide synthase in human chondrocytes Biochem Biophys Res Commun. 1993. 193: 398-405.

Park S, Gwak J, Han SJ, Oh S. Cardamonin suppresses the proliferation of colon cancer cells by promoting beta-catenin degradation. Biol Pharm Bull. 2013. 36: 1040-1044.

Turini ME, DuBois RN. Cyclooxygenase-2: a therapeutic target. Annu Rev Med. 2002. 53: 35-57.

Vallance P. Nitric oxide: therapeutic opportunities. Fundam Clin Pharmacol. 2003. 17: 1-10.

Youn HS. The Anti-Inflammatory Effects of Phytochemicals by the Modulation of Innate Immunity. J Exp Biomed Sci. 2012. 18: $181-192$

Youn HS, Lee JY, Fitzgerald KA, Young HA, Akira S, Hwang DH Specific inhibition of MyD88-independent signaling pathways of TLR3 and TLR4 by resveratrol: molecular targets are TBK1 and RIP1 in TRIF complex. J Immunol. 2005. 175: 3339-3346.

Youn HS, Lee JY, Saitoh SI, Miyake K, Hwang DH. Auranofin, as an anti-rheumatic gold compound, suppresses LPS-induced homodimerization of TLR4. Biochem Biophys Res Commun. 2006a. 350: 866-871. 
Youn HS, Lee JY, Saitoh SI, Miyake K, Kang KW, Choi YJ, Hwang DH. Suppression of MyD88- and TRIF-dependent signaling pathways of Toll-like receptor by (-)-epigallocatechin-3gallate, a polyphenol component of green tea. Biochem Pharmacol. 2006b. 72: 850-859.

Youn HS, Saitoh SI, Miyake K, Hwang DH. Inhibition of homodimerization of Toll-like receptor 4 by curcumin. Biochem Pharmacol. 2006c. 72: 62-69.
https://doi.org/10.15616/BSL.2018.24.2.102

Cite this article as: Kim AY, Shim HJ, Kim SY, Heo $\mathrm{SH}$, Youn HS. Cardamonin Inhibits the Expression of Inducible Nitric Oxide Synthase Induced by TLR2, 4, and 6 Agonists. Biomedical Science Letters. 2018. 24: 102 $-107$. 